M. O. Pozdnyshev ${ }^{1}$, orcid.org/0000-0002-1701-2257, S. O. Davydov ${ }^{2}$, orcid.org/0000-0002-4142-7217
1 - Yuzhnoye State Design Office, Dnipro, Ukraine, e-mail: n.pozdnyshev@gmail.com

2 - Oles Honchar Dnipro National University, Dnipro, Ukraine

\title{
EXPERIMENTAL RESEARCH ON HYDRAULIC RESISTANCE OF DEFORMED WOVEN MESHES
}

Purpose. Experimental verification and refinement of methodology for calculating the hydraulic resistance coefficient of meshes with micron-sized square cells for the case of deformed meshes cell whose shape differs from a square shape.

Methodology. To achieve the goal of the research, the experimental method is used. The theoretical value of the hydraulic resistance coefficient of the deformed mesh is determined based on the obtained mathematical model of the deformed mesh cell. The values of pressure losses on the meshes and their hydraulic resistance coefficients are determined using experimental blowing of the mesh samples with air. The type of empirical coefficient is determined by comparing analytical calculations and experimental results.

Findings. The values of hydraulic pressure losses are experimentally determined depending on the flow rate for various types of meshes with different values of the wire weave angle.

Originality. It was found that the values of the coefficient of hydraulic resistance of deformed meshes are less than those of undeformed ones for the same values of the mesh open area ratio. This is indicative of the influence of the cell shape not only due to the change in the mesh open area ratio, but also due to the nature of the flow around the mesh fibers when its shape changes from square to diamond. The experiments proved that this effect is observed when the wire weave angles are less than $80^{\circ}$ and can be taken into account by the empirical shape factor. The type of dependence of the shape factor on the wire weave angle has the form of a $3^{\text {rd }}$ degree polynomial function.

Practical value. By the deforming of mesh weave structure it is possible to reduce its hydraulic resistance coefficient compared to the undeformed mesh having the same open area. The analytical method for calculating the hydraulic resistance coefficient of deformed meshes depending on the wire weave angle is refined using the obtained dependence for the shape factor. The methodology consists in the multiplication of the hydraulic resistance coefficient, that is calculated on the basis of the dependences for undeformed meshes, by the value of the shape factor, that depends on the wire weave angle.

Keywords: mesh weave structure, wire weave angle, coefficient of hydraulic resistance

Introduction. Metal woven meshes with square cells are used in many technical devices for various purposes, such as liquid or gas filters [1], particulate separators [2], mixers [3], heat exchangers [4], as well as capillary phase separators [5]. An important area of the use of woven metal meshes with micron cells is their use as components of liquid acquisition devices in the systems for providing multiple launch of a spacecraft liquidpropellant rocket engine. Due to surface tension forces such phase separators hold at the entrance to the propellant management device the part of the fuel necessary for its launch [6].

The main hydrodynamic characteristics of the mesh are the hydraulic resistance coefficient and bubble point pressure [7]. One of the important characteristics of the mesh is the filtration rating, which determines the maximum size of solid particles that can penetrate through the mesh, which is important for the design of filter devices [8].

Metal woven meshes with square cells of plane (Fig. 1, $a$ ) and twill weaving (Fig. 1, $b$ ) have a complex spatial structure. The main geometric characteristics of the meshes are the mesh open area $b_{o}$ and the wire diameter $d$. In addition, the characteristic dimensions of the mesh are determined by its projection onto the plane.

For hydraulic devices, it is important to minimize the friction factor of the mesh elements in their composition, since the smaller the hydraulic pressure loss, the better the characteristics of the entire device and less energy loss. Minimum friction factor will have meshes with a maximum open area ratio $f_{c}$ and, as a result, the maximum value of the opening size $b_{o}$ [9]. However, the larger mesh opening size $b_{o}$, the lower the value of bubble point pressure, which worsens the characteristics of the mesh as a phase separator [7].

Thus, the optimization of the design of mesh devices in order to reduce the value of their flow friction factor with a satisfactory value of bubble point pressure is an urgent task.

One of the promising methods for optimizing the hydrodynamic characteristics of metal meshes with square cells of plain

(C) Pozdnyshev M. O., Davydov S. O., 2020 and twill weaving is the deformation of their weaving structure. In this case, the wire weave angle of the mesh is changed purposefully and, as a consequence, so are the cells shape, geometrical dimensions and the open area ratio $[10,11]$.

Literature review. A lot of papers have been devoted to the study of friction factor of metal woven nets of various types.

In [12], the hydraulic losses of static pressure on various types of woven meshes of plain and twill weaving were experimentally and numerically studied. During the study, an experimental setup operating in atmospheric air as a working fluid was used. However, the influence of deformation of the mesh wires on its friction factor was not considered in the study.

In [13], it was numerically studied how the geometric characteristics of the meshes and the structure of its weaving influence the hydraulic pressure loss on the mesh and the friction factor. In this work, this influence was taken into account only by means of the mesh porosity parameter, and only industrially fabricated undeformed meshes were studied.

In [14], the influence of mesh on the parameters of a gas flow through it was considered. In this paper, the meshes with square cells of large sizes were considered. The paper also presents the empirical dependences of the meshes friction factor, taking into account their open area ratio which can be used to estimate the effect of shape changes in the mesh cell on the friction factor.

In [15], the influence of the type of mesh on the magnitude of acoustic vibrations arising during the flow of air through it was studied numerically. Also, the paper presents the dependencies for taking into account the influence of the mesh open area ratio on its flow friction factor. In this work, the meshes with square cells of large sizes were studied.

In [9], some experimental data on the studies of industrially manufactured meshes with plain square mesh and very tightly woven weaves (dutch type) was summarized. Empirical dependences are presented for determining the friction factor of such meshes. However, in this work, the deformed meshes with the cell shapes different from the square shape were not considered.

In [16], the generalized results were presented of a large number of experimental studies on the flow friction factor of 


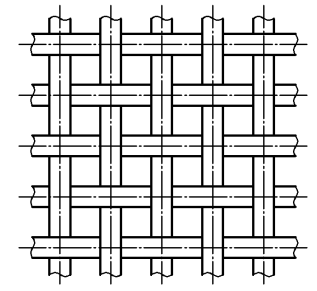

a

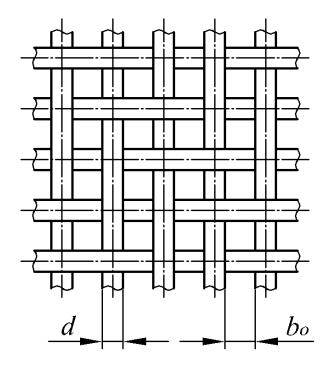

$b$

Fig. 1. Geometric parameters of metal mesh with square cells of plain (a) and full twill (b) weaving

plain weaving metal meshes as well as the empirical dependences for various types of meshes. However, all empirical dependencies are given for undeformed meshes.

The handbook [17] summarizes the results of many studies to determine the hydraulic resistance of various devices, including woven metal meshes. The presented dependences were obtained for undeformed meshes, but they allow taking their open area ratio into account.

The influence of the wire weave angle of deformed meshes on their hydrodynamic characteristics was analytically studied in $[10,11]$.

In [10], it is proposed to take into account the mesh wire weave angle by changing the open area ratio as a result of deformation of the structure of its weaving with the use of the dependences to determine friction factor of undeformed meshes.

In [11], the results of analytical calculations of the flow friction factor and bubble point pressure for some types of deformed meshes were presented, and the possibility of using devices based on them in rocket and space technology was analyzed.

However, in the last two papers, the influence of the change in a cell shape from square to rhombic one on the flow parameters of liquid and gas flow through the mesh was not taken into account. Also, the results of analytical calculations at the present moment are not confirmed by experiments for deformed meshes.

Thus, it can be noted that the studies aimed at determining the flow friction factor for various types or metal woven meshes under various conditions are an urgent task.

To verify and refine the analytical methodology for calculating the friction factor of deformed meshes whose shape of cells differs from the square shape, as well as the results of calculations based on it, it is necessary to experimentally investigate the influence of the wire weave angle on its flow friction factor.

Purpose. The aim of the research is the experimental verification and refinement of the methodology for calculating the flow friction factor of metal woven meshes with micron-sized square cells for the case of deformed mesh whose cell shape differs from the square shape. tasks:

To achieve this aim, it is necessary to solve the following

- to determine experimentally the value of pressure loss on various types of meshes with different values of the wire weave angle at various flow rates;

- to establish possible differences between the values of the flow friction factor of deformed and undeformed meshes with the same value of the open area ratio;
- to determine an empirical dependence that takes into account the influence of mesh cell shape changes on its friction factor.

Mathematical model of the deformed mesh cell. When the mesh weaving structure is deformed by changing wire weave angle, the cell opening shape changes from square to rhomboid shape (Fig. 2).

When the mesh is deformed, all the characteristic sizes of its cells change depending on the wire weave angle [10].

Suppose that with slight changes in the wire weave angle, the distance between the wire contact points does not change (Fig. 2) and, accordingly, is equal to the distance of the undeformed mesh. The width of the strips of mesh wires projection onto the plane corresponds to the diameter of its wires [10].

Using geometric transformations, we obtain the expressions for determining the geometric parameters of a deformed mesh cell depending on the wire weave angle. The cell length will be determined by expression

$$
a=b_{o}+d \cdot\left(1-\frac{1}{\sin (\varphi)}\right) \text {. }
$$

Cell width will be determined by expression

$$
b=\left(b_{o}+d\right) \cdot \sin (\varphi)-d .
$$

The width of the cell $b$ is also the minimum distance between the wires of the mesh and thereby determines the filtration rating of the mesh. Thus, the maximum diameter of a spherical particle that can penetrate through a filter made of a deformed mesh having the wire weave angle $\varphi$ will correspond to a value of $b$.

The opening area of the deformed mesh cell, as a function depending on the wire weave angle $F_{\mathrm{o}}(\varphi)$, taking into account expression $(1,2)$, can be represented as

$$
F_{o}(\varphi)=a \cdot b=\left[b_{o}+d \cdot\left(1-\frac{1}{\sin (\varphi)}\right)\right] \cdot\left[\left(b_{o}+d\right) \cdot \sin (\varphi)-d\right] .
$$

Total area of the deformed mesh cell, as a function depending on the wire weave angle $F_{c}(\varphi)$, taking into account expression $(1,2)$, will have the form

$$
F_{c}(\varphi)=\left(b_{o}+d\right)^{2} \cdot \sin (\varphi) .
$$

Then, the open area ratio, taking into account expression $(3,4)$, is determined as the ratio of an effective area to the total area of the mesh according to the following expression

$$
\begin{aligned}
f_{c}(\varphi)= & \frac{F_{o}(\varphi)}{F_{c}(\varphi)}=\frac{\left[b_{o}+d \cdot\left(1-\frac{1}{\sin (\varphi)}\right)\right]_{x}}{\left(b_{o}+d\right)^{2} \cdot \sin (\varphi)} \times \\
& \times\left[\left(b_{o}+d\right) \cdot \sin (\varphi)-d\right] .
\end{aligned}
$$

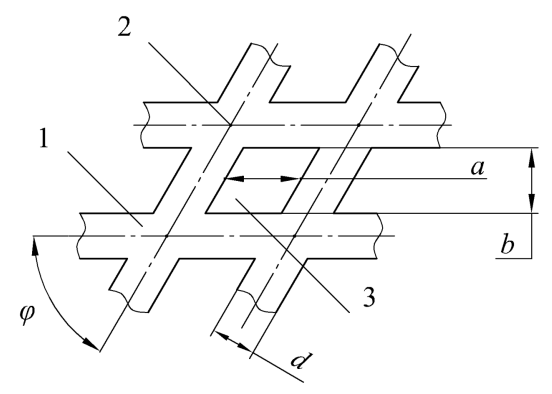

Fig. 2. The projection of a deformed mesh cell onto a plane:

1 - mesh wire projection; 2 - wire contact point; 3 - mesh cell opening; $\varphi$ - wire weave angle, degree; $a$ - cell length, $m ; b$ - cell width, $m ; d$ - wire diameter, $m$ 
There is also a critical wire weave angle of the mesh $\varphi_{c}$, at which, according to the model used, the mesh opening is completely blocked by its wires. Substituting $F_{o}=0$ into expression (3) we obtain the analytical dependence for determining the critical wire weave angle, then

$$
\varphi_{c}=\arcsin \left(\frac{d}{b_{o}+d}\right) \text {. }
$$

Due to the complex spatial structure of the mesh, with a decrease in the wire weave angle, its additional deformation can exceed the calculated one.

Measurements on mesh samples performed in [18] showed that with a decrease in the wire weave angle, the mesh opening size in some cases becomes less than the theoretically calculated one. The maximum recorded deviation of the actual value of the mesh cell size from the theoretically calculated one due to the deformation of the wires did not exceed $3 \%$. There was also a significant variation in the measured value.

Thus, the observed correlation of the mesh opening size, depending on the wire weave angle, taking into account a large scatter of the measured value and a small absolute value, does not allow us to unambiguously establish the dependence for taking this phenomenon into account and requires additional research. In this paper, we will consider this phenomenon as insignificant.

Given the above, expressions (1-5) are relevant for insignificant deformation of the mesh, when the wire weave angle significantly exceeds the critical wire weave angle defined by expression (6).

Methods. The mesh in the hydraulic system is the local flow resistance. Hydraulic losses of static pressure at the local flow resistance $\Delta p$ are determined on the basis of the EulerBernoulli equation in the form $[9,12,17]$

$$
\Delta p=\xi \cdot \frac{\rho \cdot v^{2}}{2},
$$

where $\xi$ is the local flow friction factor; $r$ is density of fluid or gas, $\mathrm{kg} / \mathrm{m}^{3} ; v$ is average flow rate velocity, $\mathrm{m} / \mathrm{s}$.

Given the expression (7) the flow friction factor of mesh $\xi_{\mathrm{e}}$ will be calculated by the dependence

$$
\xi_{e}=\frac{\Delta p_{e}}{\frac{\rho \cdot v_{e}^{2}}{2}},
$$

where $\Delta p_{e}$ is the value of static pressure loss on the mesh, Pa; $v_{e}$ is the average flow rate in front of the mesh, m/s.

Thus, to determine the flow friction factor of the mesh $\xi_{e}$ it is necessary to experimentally measure the values of the static pressure losses on it $\Delta p_{e}$ at various flow rates.

According to a lot of research $[9,12,16]$, the experimentally determined flow friction factor of the mesh $\xi_{c}$ will have the form of a function

$$
\xi_{c}=\frac{\alpha}{R e_{c}}+\beta,
$$

where $\alpha, \beta$ are experimentally determined dimensionless empirical coefficients; $R e_{c}$ is the Reynolds number inside the mesh cell, which is determined by dependence [17]

$$
\operatorname{Re}_{c}=\frac{v_{e} \cdot d}{\mathrm{v} \cdot f_{c}}
$$

where $v$ is kinematic viscosity of liquid or gas, $\mathrm{m}^{2} / \mathrm{s}$.

Taking into account dependence (8), the key factors in determining $\xi_{e}$ are the coefficients $\alpha$ and $\beta$.

In $[10,11]$, for analytical determining the flow friction factor of the meshes with a deformed weave structure, the experimental dependence that has the form of function (9) is used. According to the method used, the value of the mesh friction factor depends on the Reynolds number $R e_{c}$ and the open area ratio $f_{c}$ according to the following dependences.

For large values of the Reynolds number $R e_{c}>10^{3}$, the friction factor of the mesh is determined based on only the value of open area ratio according to the dependence $[14,15,17]$

$$
\xi_{c}=\xi_{f}=1.3 \cdot\left(1-f_{c}\right)+\left(\frac{1}{f_{c}}-1\right)^{2} .
$$

For small Reynolds numbers $R e_{c}<50$, the flow friction factor of the mesh is determined not only by the open area ratio, but also by the corresponding Reynolds number $R e_{c}$.

Taking into account expressions (9-11), the flow friction factor of the mesh in this regime is determined by the following dependence [17]

$$
\xi_{c}=\frac{22}{R e_{c}}+\xi_{f} .
$$

In the transitional regime, at values of the Reynolds number $50<R e_{c}<10^{3}$, the flow friction factor of the mesh was determined by the following dependence [17]

$$
\xi_{c}=k_{R e} \cdot \xi_{f},
$$

where $k_{R e}$ is the empirical influence coefficient of the Reynolds number (Table 1).

The empirical dependences (11-13) are determined for undeformed metal woven meshes with square cells and do not take into account the change in the shape of cell to a rhombus shape during the deformation of its weaving structure.

The influence of the wire weave angle $\varphi$ on the open area ratio $f_{c}$ for analytical calculations was taken into account using expression (5) [10].

To determine the influence of the cell shape on the flow parameters, we introduce a dimensionless shape factor $k_{f}$ as a function of the wire weave angle $\varphi$. Then, taking into account expressions $(7-13)$, the dependence of the flow friction factor of the deformed mesh $\xi_{d}$ will have the form

$$
\xi_{e}=\xi_{e}(\varphi)=k_{f}(\varphi) \cdot \xi\left(f_{c}, R e\right) .
$$

Then, taking into account (14), the shape factor as a function of the wire weave angle $k_{f}(\varphi)$ can be determined experimentally by the dependence

$$
k_{f}(\varphi)=\frac{\xi_{e}(\varphi)}{\xi_{c}(\varphi)},
$$

where $\xi_{e}(\phi)$ is an approximating function of dependence of the mesh friction factor on the wire weave angle, determined experimentally; $\xi_{c}(\phi)$ is the function of dependence of the mesh friction factor on the wire weave angle, determined analytically using dependencies $(5,9-13)$.

To create experimental samples, the industrially manufactured metal mesh was deformed on a special setup, then fixed between two nozzles with a diameter of $19 \mathrm{~mm}$ using polymer glue.

Table 2 shows the types and characteristics of the metal woven meshes with square cells that were used as experimental samples, as well as the obtained wire weave angles for deformed samples.

It should be noted that the primary mesh was deformed without significant effort, thereby minimizing the possible additional deformation of the wires and the influence of this factor on the geometric parameters of the experimental mesh samples.

Table 1

Values of the empirical coefficient $k_{R e}$ depending on the Reynolds number $\operatorname{Re}$ [17]

\begin{tabular}{|c|c|c|c|c|c|c|c|c|}
\hline$R e$ & 50 & 100 & 150 & 200 & 300 & 400 & 500 & $10^{3}$ \\
\hline$k_{R e}$ & 1.44 & 1.24 & 1.13 & 1.08 & 1.03 & 1.01 & 1.01 & 1.0 \\
\hline
\end{tabular}


During the experimental research the atmospheric air was used as a working fluid. The main physical characteristics of atmospheric air at the temperatures of the experiment are given in Table 3.

For this research, the experimental setup was used the scheme of which is shown in Fig. 3.

Measurement of the pressure loss on the mesh sample $\Delta p$ is made using the static pressure differential sensor 1 , micromanometer type MMN-2400. The air flow is created using a centrifugal air pump 5 . The flow rate $v$ is measured using a flow rate sensor 4, a turbine flowmeter TDR 12-2-3 type.

Tests of each sample are taken in the following sequence:

1 . The mesh sample 3 is hermetically mounted in the experimental setup.

2. The air pump 5 is turned on at the minimum power mode to set the minimum flow rate through the mesh.

3. The flow rate sensor 4 indications are recorded, as well as the value of the static pressure losses $\Delta p$ on the mesh sample using the differential pressure sensor 1 ( 5 consecutive measurements are made in this mode).

4. Point 3 is repeated for the middle and maximum power modes of the air pump 5 .

5. The air pump 5 is turned off, sample 3 is removed and the next test sample is mounted. Then the test cycle is repeated for the next sample.

The flow rate determined by the flow rate sensor is a linear function depending on the frequency of the sensor indications impulses and characterized by the following dependence

$$
v_{e}=v_{e}(\gamma)=A+B \cdot \gamma,
$$

where $A, B$ are empirical coefficients determined during calibration of the flow rate sensor on a given liquid or gas; $\gamma$ is signal frequency indication of the flow rate sensor output, $\mathrm{Hz}$.

To calibrate the flow of the rate sensor and determine the empirical coefficients $A, B$, it is necessary to measure pressure losses and sensor indications at the reference local resistance. In this case, it is advisable to calibrate the flow rate sensor using the meshes on which the experiment is done (on undeformed samples).

Table 2

Types of investigated metal meshes (full twill weaving type)

\begin{tabular}{|c|c|c|c|c|}
\hline No & $\begin{array}{c}\text { Mesh } \\
\text { opening } \\
\text { size, } b_{o}, \mu \mathrm{m}\end{array}$ & $\begin{array}{c}\text { Wire } \\
\text { diameter, } \\
d, \mu \mathrm{m}\end{array}$ & $\begin{array}{c}\text { Wire weave } \\
\text { angle, } \varphi, \text { degree }\end{array}$ & $\begin{array}{c}\text { Mesh } \\
\text { material }\end{array}$ \\
\hline 1 & 63 & 50 & $85,72,62$ & Stainless steel \\
\hline 2 & 63 & 40 & $90,57,46,42$ & Brass \\
\hline 3 & 50 & 40 & $90,67,65,63,55$ & Brass \\
\hline 4 & 40 & 30 & $90,76,67$ & Stainless steel \\
\hline 5 & 32 & 28 & $90,76,73,70,63$ & Stainless steel \\
\hline
\end{tabular}

Table 3

The main physical characteristics of the air at the atmospheric pressure accepted for calculations

\begin{tabular}{|c|c|c|}
\hline Temperature, ${ }^{\circ} \mathrm{C}$ & $\begin{array}{c}\text { Density, } \\
\rho, 10^{-3} \mathrm{~kg} / \mathrm{m}^{3}\end{array}$ & $\begin{array}{c}\text { Kinematic viscosity, } \\
v, 10^{-2} \mathrm{~m}^{2} / \mathrm{s}\end{array}$ \\
\hline 16.5 & 1.219 & 1.433 \\
\hline 17 & 1.217 & 1.436 \\
\hline 20 & 1.205 & 1.455 \\
\hline 20.5 & 1.202 & 1.459 \\
\hline 21.5 & 1.200 & 1.462 \\
\hline 22 & 1.198 & 1.465 \\
\hline
\end{tabular}

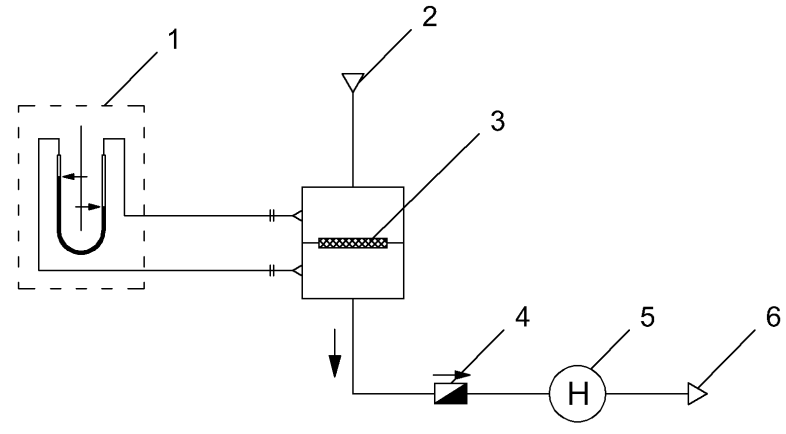

Fig. 3. Scheme of experimental setup:

1 - differential static pressure sensor; 2 - air inlet; 3 - mesh sample; 4 - flow rate sensor; 5 - air pump; 6 - air outlet

Taking into account dependence (7), the value of the hydraulic losses of static pressure is a function depending on the flow rate $\Delta p(v)$. In this case, the flow friction factor of the mesh $\xi$ will be determined using the dependences for undeformed meshes $(9-13)$.

Substituting dependence (16) into (7), we obtain a function for approximating the calibration results of the flow rate sensor $\Delta p_{e}(\gamma)$. To obtain the function of the dependence of the flow rate velocity on the frequency of the flow rate sensor indications $v_{e}(\gamma)$, we equate the numerical values determined analytically using the function $\Delta p(v)$ to the values obtained from the calibration of the flow rate sensor $\Delta p_{e}(\gamma)$

$$
\Delta p=\Delta p(v)=\Delta p_{e}=\Delta p_{e}(\gamma) .
$$

The obtained numerical values of the flow rate velocity $v$ and the frequency of the flow rate sensor indications $\gamma$ are approximated by the least square method to obtain a function (16), where $A$ and $B$ are the required coefficients.

To increase the accuracy of the experimental results and compensate the influence of the type of mesh, the flow rate sensor is calibrated for each individual type of the mesh. Thus, the air flow rate through each sample of a deformed mesh will be determined relative to an undeformed sample of the same type, which allows one to more accurately determine the influence of the mesh weave angle.

Table 4 shows the values of empirical coefficients $A$ and $B$ of function (16) according to the results of calibration of the flow rate sensor 4 .

Results. The measurement of the hydraulic pressure loss on the mesh samples was taken at air flow rates $v$ from 13.6 to $22.9 \mathrm{~m} / \mathrm{s}$. The flow velocity data correspond to the Reynolds numbers in the mesh cell of the Re from 98 to 294 .

Figs. 4-8 show the results of experimental measurements of pressure losses $\Delta p$ on the experimental samples of meshes (Table 2) depending on the air flow velocity through the mesh $v$. The points in the figures correspond to experimentally measured values. The approximating lines are built using the least square method for the corresponding experimental points.

Figs. 4-8 show that with a decrease in the mesh weave angle, the hydraulic pressure losses increase in all test modes for

Table 4

Flow rate sensor calibration results

\begin{tabular}{|c|c|c|}
\hline No. of mesh (Table 2) & $A$ & $B$ \\
\hline 1 & 6.091 & 0.0132 \\
\hline 2 & 3.492 & 0.0155 \\
\hline 3 & 3.483 & 0.0144 \\
\hline 4 & 3.544 & 0.0217 \\
\hline 5 & 3.930 & 0.0160 \\
\hline
\end{tabular}




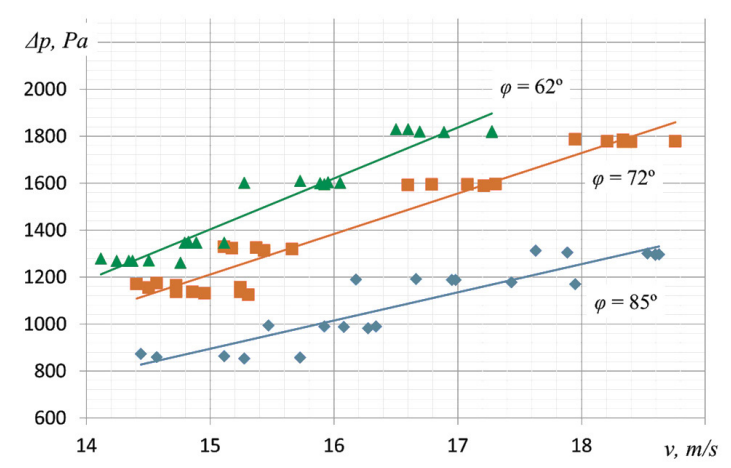

Fig. 4. Variation of pressure loss $\Delta p$ vs. flow rate $v$ on mesh samples No. $1(63 / 50)$

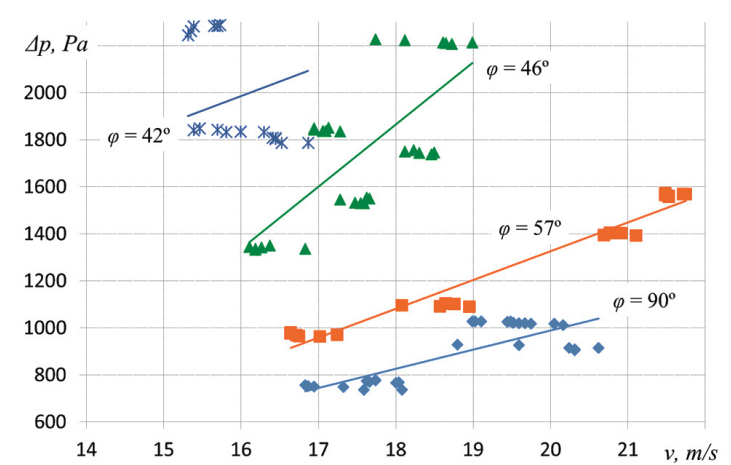

Fig. 5. Variation of pressure loss $\Delta p$ vs. flow rate $v$ on mesh samples No. 2(63/40)

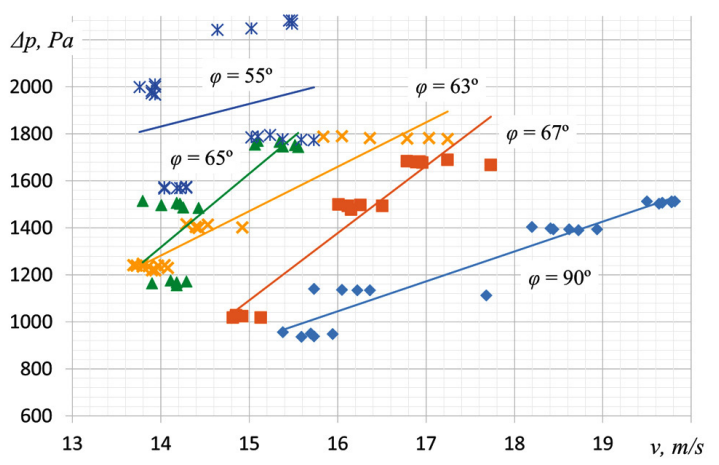

Fig. 6. Variation of pressure loss $\Delta p$ vs. flow rate $v$ on mesh samples No. 3(50/40)

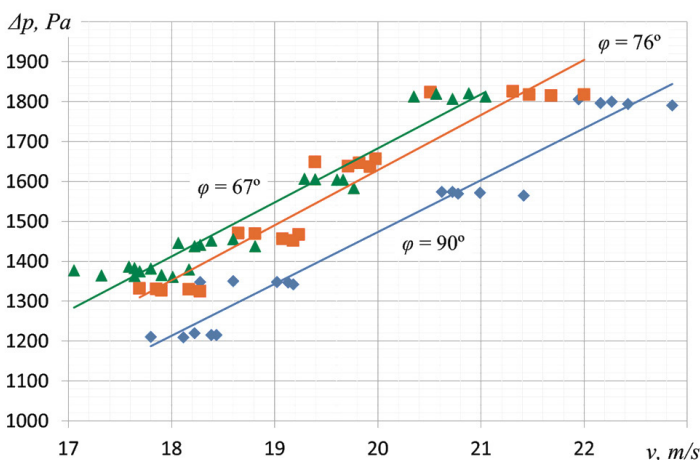

Fig. 7. Variation of pressure loss $\Delta p$ vs. flow rate $v$ on mesh samples No. 4(40/30)

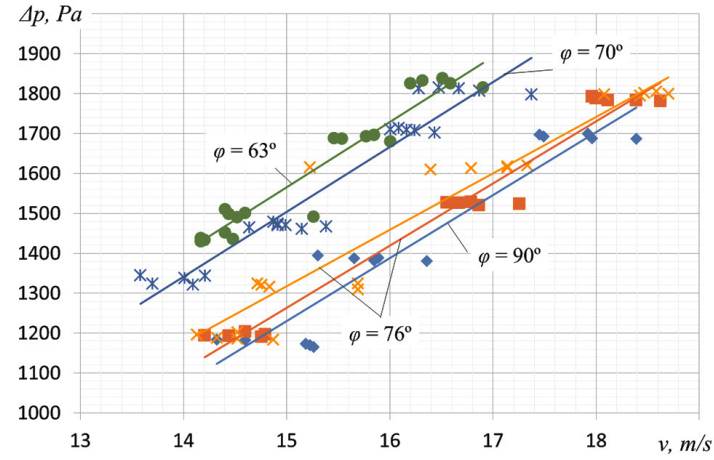

Fig. 8. Variation of pressure loss $\Delta p$ vs. flow rate $v$ on mesh samples No. 5(32/28)

all types of meshes. Approximating straight lines built by the least square method using the experimental points for meshes of the same type have a similar angle of inclination. Also, from Fig. 8, it can be observed that for different samples of meshes with the same weave angle the values of the pressure loss are practically identical (mesh samples No. $5, \varphi=76^{\circ}$ ). Together, this indicates the correctness of the measurement results.

On some mesh samples, the results of the pressure loss measurements depending on the flow rate velocity have a different growth pattern relative to similar samples. On one of the samples (mesh samples No. $3, \varphi=65^{\circ}$ ) the pressure loss values are slightly higher than in the sample with a smaller weave angle (mesh samples No. $3, \varphi=63^{\circ}$ ). This deviation can be explained by the errors in the indications of the flow rate sensor, as well as possible intrusion of dust and contamination of an individual mesh sample, which, as a result, can contribute to higher values of the pressure loss for samples with a larger wire weave angle. Taking into account a large number of experimental measurements and small value of the deviation, this single deviation can be considered insignificant.

Based on the obtained experimental data, taking into account expression (8), the dependences of the mesh friction factor $\xi_{e}$ on its open area ratio $f_{c}$ for all samples were determined (Fig. 9).

Fig. 9 shows that the flow friction factor of the mesh $\xi_{e}$ is expected to increase with decreasing open area ratio $f_{c}$. However, it can be observed that for the same values of $f_{c}$ the flow friction factor of deformed meshes is lower than for undeformed ones. This may indicate the influence of the cell shape on the parameters of the flow around the mesh wires with gas and, thus, on the value of the friction factor. This effect becomes more significant with the decrease in the open area ratio $f_{c}$, which corresponds to the increase in the mesh deformation (decrease in the angle $\varphi$ ).

Thus, it can be argued that in practice, by deforming the mesh weaving structure, it is possible to reduce the flow friction factor relatively to an undeformed mesh having the same open area ratio.

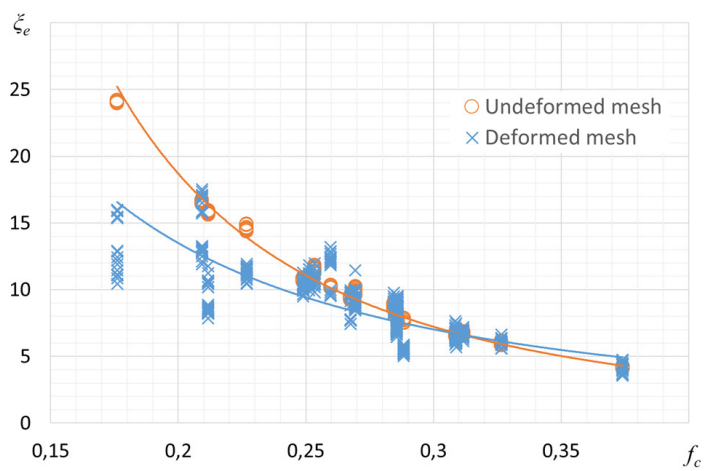

Fig. 9. Variation of mesh friction factor $\xi_{e} v s$. open area ratio $f_{c}$ 


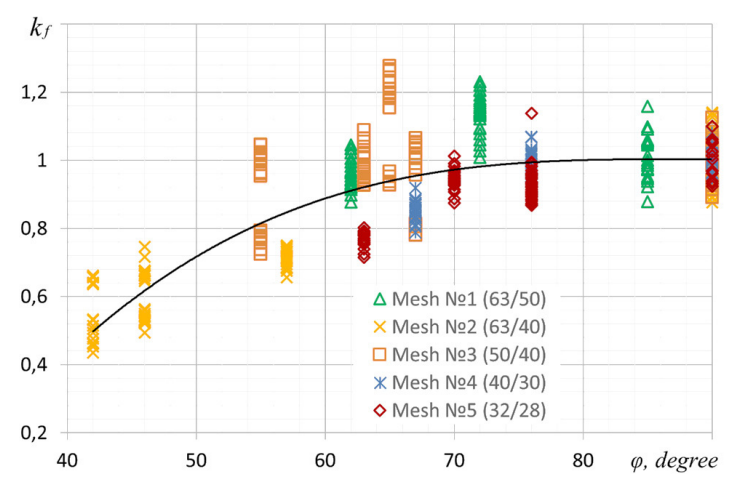

Fig. 10. Variation of shape factor $k_{f} v s$. mesh weave angle $\varphi$

For each experimentally determined point, the value of the flow friction factor of the mesh $\xi_{c}$ is analytically determined using dependences $(9-13)$. Then, using the dependence (15), the values of the shape factor $k_{f}$ are determined depending on the mesh weave angle $\varphi$ (Fig. 10).

To obtain the empirical dependence of the shape factor on the mesh weave angle as a function $k_{f}(\varphi)$, we approximate the experimental values (Fig. 10) using the least squares method. A $3^{\text {rd }}$-degree polynomial function is the most similar to the field of experimental values.

Approximating the experimental data by the least square method using a $3^{r d}$-degree polynomial function, we obtain

$k_{f}=5.063 \cdot 10^{-6} \cdot \varphi^{3}-1.344 \cdot 10^{-3} \cdot \varphi^{2}+0.119 \cdot \varphi-2.515$.

According to Fig. 10 and dependence (18), the influence of the shape change of the mesh cell on its flow friction factor relative to the result obtained using the analytical method becomes significant at mesh weaving angles $\varphi<80^{\circ}$. This may indicate the best parameters of gas flowing through the mesh due to a change in the shape of its cells from square to rhombic ones. It can be assumed that this occurs due to a decrease in the distance between the wires with a constant diameter and, thus, an increase in the $d / b_{o}$ ratio, which creates better parameters for the flow around the wire.

Consequently, based on the results of the research, the true value of the flow friction factor of the mesh, taking into account the wire weave angle, can be determined by the following algorithm:

1. The value of the flow friction factor is determined by the dependences for undeformed meshes $\xi_{c}$ (for example, according to the methodology [17]) using expressions (11-13), taking into account the influence of the mesh weave angle $\varphi$ on the open area ratio $f_{c}$ determined by expression (5).

2 . The obtained value of $\xi_{c}$ is multiplied by the value of the shape factor $k_{f}$ at a known value of the mesh weave angle $\varphi$ according to expressions $(14,18)$ and, thus, the true value of the mesh friction factor is determined.

For values of the mesh weave angle $\varphi>80^{\circ}$ the shape factor $k_{f}$ can be ignored in analytical calculations of the flow friction factor of deformed meshes.

Conclusions.

1. The experimental research was conducted on the friction factor of metal woven meshes with micron-sized square cells for the case of deformed meshes whose cell shape differs from a square shape. The values of hydraulic pressure losses on the meshes were experimentally determined depending on the mesh weave angle at air flow velocities $v$ from 13.6 to $22.9 \mathrm{~m} / \mathrm{s}$, which corresponds to the Reynolds numbers in the mesh cells $R e$ from 98 to 294 . The mesh weave angle of mesh samples $\varphi$ ranged from 42 to $90^{\circ}$.

2. It was experimentally established that the mesh weave angle affects the flow friction factor of the meshes not only due to a change in the open area ratio, but also as a result of a change in the parameters of the flow of gas around the wires. This effect becomes significant at mesh weaving angles $\varphi<80^{\circ}$. In practice, it has been shown that by deforming the mesh weave structure, it is possible to reduce the mesh friction factor relative to an undeformed mesh that has the same open area ratio $f_{c}$.

3 . The results of the research indicate that in the analytical calculations of the flow friction factor of meshes with a deformed weaving structure, for the wire weave angle $\varphi<80^{\circ}$, the calculated value of the flow friction factor must be multiplied by the shape factor $k_{f}$ according to expressions $(14,18)$.

4. The results of this work can be used for hydraulic calculations of devices with mesh elements: filters, mixers, heat exchangers, particulate separators, capillary phase separators of liquid and gas, and other devices.

5. Further research may be of practical interest in the direction of refinement of experimental results on a more types of meshes, large ranges of weave angles $\varphi$ and the Reynolds numbers $R e$, as well as on other working gases and liquids.

\section{References.}

1. Huang, S., Zhang, X., Tafu, M., Toshima, T., \& Jo, Y. (2015). Study on subway particle capture by ferromagnetic mesh filter in nonuniform magnetic field. Separation and Purification Technology, 156, 642-654. https://doi.org/10.1016/j. seppur.2015.10.060.

2. Mondal, S., Wu, C. H., Sharma, M.M., Chanpura, R.A., Parlar, M., \& Ayoub, J.A. (2016). Characterizing, designing, and selecting metal mesh screens for standalone-screen applications. SPE Drilling \& Completion, 31(02), 85-94. https:// doi.org/10.1016/j.seppur.2015.10.060.

3. Hweij, K.A., \& Azizi, F. (2015). Hydrodynamics and residence time distribution of liquid flow in tubular reactors equipped with screen-type static mixers. Chemical engineering journal, 279, 948-963. https://doi.org/10.1016/j.cej.2015.05.100. 4. Avila-Marin, A. L., Fernandez-Reche, J., Casanova, M., Caliot, C., \& Flamant, G. (2017). Numerical simulation of convective heat transfer for inline and stagger stacked plain-weave wire mesh screens and comparison with a local thermal non-equilibrium model. In AIP Conference Proceedings, 1850(1), (pp. 030003). AIP Publishing LLC. https://doi.org/10.1063/1.4984346.

5. Hartwig, J. W. (2017). Propellant Management Devices for Low-Gravity Fluid Management: Past, Present, and Future Applications. Journal of Spacecraft and Rockets, 54(4), 808824. https://doi.org/10.2514/1.a33750.

6. Davydov, S. O., \& Horelova, K. V. (2012). History of design development and prospects of using tools to provide continuity of fuel based on capillary strength. Visnyk Dnipropetrovskoho Universytetu. Seriia istoriia i filosofiia nauky i tekhniky (20), 160-164.

7. Hartwig, J.W. (2015). Liquid acquisition devices for advanced in-space cryogenic propulsion systems. Academic Press, 488. https://doi.org/10.1016/C2014-0-03511-3.

8. Mondal, S., Wu, C. H., Sharma, M. M., Chanpura, R.A., Parlar, M., \& Ayoub, J. A. (2016). Characterizing, designing, and selecting metal mesh screens for standalone-screen applications. SPE Drilling \& Completion, 31(02), 85-94. https:// doi.org/10.2118/170935-PA.

9. Yershin, S.A. (2017). Experimental Study of Channel Flow with Porous Walls. In Paradoxes in Aerohydrodynamics, (pp. 149-173). Cham^ ${ }^{\wedge}$ Springer. https://doi.org/10.1007/978-3319-25673-3 6 .

10. Pozdnyshev, M. O. (2012). Influence of deformity of mesh weave structure on project parameters of a netted phase separator. Visnyk Dnipropetrovskoho Universytetu. Seriia raketnokosmichna tekhnika, 20(4), 227-236.

11. Pozdnyshev, M. O. (2013). Hydrodynamic characteristics of meshes with changed weave structure. Systemne proektuvannia ta analiz kharakterystyk aerokosmichnoi tekhniky, (15), 75-80.

12. Yoshida, Y., Inoue, Y., Shimosaka, A., Shirakawa, Y., \& Hidaka, J. (2015). Numerical Simulation of Flow Resistivity of Metal Woven Mesh. Journal of Chemical Engineering of Japan, 48(7), 545-555. https://doi.org/10.1252/jcej.14we148. 
13. Cohen, M. (2015). Modelling of Airflow through Wire Mesh Security Screens. The UNSW Canberra at ADFA Journal of Undergraduate Engineering Research, 8(1).

14. Okolo, P. N., Zhao, K., Neri, E., Kennedy, J., \& Bennett, G.J. (2015). CAA noise reduction parametric study of mesh screens applied to landing gears. In $22^{\text {nd }}$ International Congress on Sound and Vibration, 12.

15. Okolo, P. N., Zhao, K., Kennedy, J., \& Bennett, G.J. (2017). Numerical Modeling of Wire Screens for Flow and Noise Control. In 23 $3^{\text {rd }}$ AIAA/CEAS Aeroacoustics Conference, (p. 3700). https://doi.org/10.2514/6.2017-3700.

16. Azizi, F. (2019). On the pressure drop of fluids through woven screen meshes. Chemical Engineering Science, 207, 464478. https://doi.org/10.1016/j.ces.2019.06.046.

17. Idelchik, I. E. (2017). Flow Resistance: A Design Guide for Engineers. CRC Press.

18. Pozdnyshev, M. O. (2019). Diffraction method for measuring geometrical parameters of meshes. Systemne proektuvannia ta analiz kharakterystyk aerokosmichnoi tekhniky, (26), 108-114.

\section{Експериментальне дослідження гідравлічного опору деформованих сіток}

$$
\text { М. О. Позднишев }{ }^{1} \text {, С. О. Давидов }{ }^{2}
$$

1 - Державне підприємство «Конструкторське бюро «Південне» імені М.К. Янгеля», м. Дніпро, Україна, e-mail: n.pozdnyshev@gmail.com

2 - Дніпровський національний університет імені Олеся Гончара, м. Дніпро, Україна

Мета. Експериментальне підтвердження та уточнення методики розрахунку коефіцієнту гідравлічного опору сіток із квадратними вічками мікронних розмірів для випадку деформованих сіток, форма вічка яких відрізняється від квадратної.

Методика. Для досягнення мети дослідження використовується розрахунково-експериментальна методика. На основі отриманої математичної моделі деформованого вічка сітки теоретично визначається коефіцієнт гідравлічного опору деформованої сітки. За допомогою експериментальної продувки зразків деформованих сіток визначаються величини втрат тиску, а також значення їх коефіцієнта гідравлічного опору. У результаті порівняння аналітичних розрахунків і експериментальних результатів визначається уточнюючий емпіричний коефіцієнт форми.

Результати. Експериментально визначені величини гідравлічних втрат тиску в залежності від швидкості потоку на різних типах сіток з різним значенням кута переплетіння волокон.

Наукова новизна. Встановлено, шо за однакових значень коефіцієнта живого перетину сітки, значення коефіцієнта гідравлічного опору деформованих сіток нижче, ніж недеформованих. Це свідчить про вплив форми вічка не тільки за рахунок зміни коефіцієнта живого перетину, але й характеру обтікання волокон сітки потоком при зміні іiі форми з квадратної на ромбічну. Експериментально встановлено, що даний вплив стає істотним при кутах переплетіння волокон сітки менше $80^{\circ}$ і може бути врахований за допомогою емпіричного коефіцієнта форми. Характер залежності коефіцієнта форми від кута переплетіння волокон має вигляд поліноміальної функції 3-го степеня.

Практична значимість. Показано, що за допомогою деформування структури плетіння волокон сітки можливо знизити коефіцієнт ії гідравлічного опору у порівнянні з недеформованою сіткою, що має однаковий коефіцієнт живого перетину. За допомогою отриманої залежності для коефіцієнта форми уточнена аналітична методика розрахунку значення коефіцієнта гідравлічного опору деформованих сіток у залежності від кута переплетіння їх волокон. Методика полягає у знаходженні добутку коефіцієнта гідравлічного опору, розрахованого на основі за- лежностей для недеформованих сіток, та коефіцієнта форми в залежності від кута переплетіння волокон.

Ключові слова: структура плетіння сітки, кут переплетіння волокон, коефіцієнт гідравлічного опору

\section{Экспериментальное исследование гидравлического сопротивления деформированных сеток}

\author{
Н. О. Позднышев ${ }^{1}$, С. А. Давыдов
}

1 - Государственное предприятие «Конструкторское бюро «Южное» имени М.К. Янгеля», г. Днепр, Украина, e-mail: n.pozdnyshev@gmail.com

2 - Днепровский национальный университет имени Олеся Гончара, г. Днепр, Украина

Цель. Экспериментальное подтверждение и уточнение методики расчёта коэффициента гидравлического сопротивления сеток с квадратными ячейками микронных размеров для случая деформированных сеток, форма ячеек которых отличается от квадратной

Методика. Для достижения цели исследования, используется расчестно-экспериментальная методика. На основе полученной математической модели деформированной ячейки сетки определяется теоретическое значение коэффициента гидравлического сопротивления деформированной сетки. С помощью продувки образцов сетки воздухом экспериментально определяются величины потерь давления на сетках и их коэффициента гидравлического сопротивления. В результате сравнения аналитических расчетов и экспериментальных результатов определяется уточняющий эмпирический коэффициент формы.

Результаты. Экспериментально определены величины гидравлических потерь давления в зависимости от скорости потока на различных типах сеток с различным значением угла переплетения волокон.

Научная новизна. Установлено, что при одинаковых значениях коэффициента живого сечения сетки, значения коэффициента гидравлического сопротивления деформированных сеток ниже, чем недеформированных. Это свидетельствует о влиянии формы ячейки не только за счет изменения коэффициента живого сечения, но и характера обтекания потоком волокон сетки при изменении ее формы с квадратной на ромбовидную. Экспериментально установлено, что данное влияние становится существенным при углах переплетения волокон сетки меньше $80^{\circ}$ и может быть учтено посредством эмпирического коэффициента формы. Характер зависимости коэффициента формы от угла переплетения волокон имеет вид полиномиальной функции 3-й степени.

Практическая значимость. Показано, что с помощью деформирования структуры плетения волокон сетки возможно снизить коэффициент ее гидравлического сопротивления по сравнению с недеформированной сеткой, имеющей такой же коэффициент живого сечения. С помощью полученной зависимости для коэффициента формы уточнена аналитическая методика расчета коэффициента гидравлического сопротивления деформированных сеток в зависимости от угла переплетения их волокон. Методика заключается в нахождении произведения коэффициента гидравлического сопротивления, рассчитанного на основе зависимостей для недеформированных сеток, и значения коэффициента формы в зависимости от угла переплетения волокон.

Ключевые слова: структура плетения сетки, угол переплетения волокон, коэффициент гидравлического сопротивления

Recommended for publication by M.M.Dron, Doctor of Technical Sciences. The manuscript was submitted 08.04.20. 